"Let us bury the hatchet! Why should scientific men quarrel?" I signified my full acceptance of the offered peace, and great was my surprise soon after to find that, unmindful of the understood compact, he had exhumed his hatchet and was dealing me unexpected and wanton strokes, tempered by a certain amount of half praise which reminds me of the sort of caressing remonstrance of Majendie in the pre-anæsthetic days, to the dog which he had on his operating table--" Taisez vous, pauvre bête!"

In all seriousness, however, I must again ask, what is the meaning of the "personal antagonism" and the persistent attacks which Dr. Carpenter, for the last six years, has directed against me? In his recently published book, in the Nineteenth Century, and in his last letter to you, the key-note struck in the Quarterly Revieze six years ago is sustained. We have the same personalities, the same somewhat stale remark about my double nature, and the same exuberance of that most dangerous and misleading class of averments, half truths. Dr. Carpenter, indeed, condescends to admit that I have pursued "with rare ability and acuteness a delicate physical investigation in which nothing is taken for granted without proof satisfactory to others as well as to himself," and that I have "carried out a beautiful inquiry in a manner and spirit worthy of all admiration;" but, after granting so much, he dissembles bis love and proceeds to "kick me down stairs." I am damned with faint praise, and put to rights in such a school-masterly style, that I could almost fancy Dr. Carpenter carries a birch rod concealed in his coat-sleeve. He admits that in an humble and subordinate sphere I have done useful work, only I must not give myself airs on that account. Dr. Carpenter reminds me of Dr. Jolnson defending Sir John Hawkins, when he was accused of meanness. "I really believe him," said Johnson, "to be an honest man at the bottom; but to be sure he is penurious, and he is mein, and it must be owned he has a degree of brutality, and a tendency to savageness, that cannot easily be defended." In the same magnanimous spirit Dr. Carpenter allows that I have contributed a trifle to science, but he does not forget to add that I am the victim of cerebral duplicity, and I am again held up to illustrate the sad result of neglecting to train and discipline "the whole mind during the period of its development," \&c.

I have, it appears, two allotropic personalities, which I may designate, in chemical language, Ortho-Crookes and PseudoCrookes. The Ortho-Crookes, according to Dr. Carpenter, has acquired " deserved distinction as a chemist." He carries out a "beautiful inquiry in a manner and spirit worthy of all admira. tion." He has shown "ability, skill, perseverance, and freedom from prepossession." He purstes "with rare ability and astuteness a delicate physical investigation." He evinces the "spirit of the true philosopher" and he has "deservedly" received "from the Royal Society the award of one of its chief dis. tinctions."

But Pseudo-Crookes, whose career Dr. Carpenter has evidently watched almost from his cradle-as he professes to know the details of his early education-unfortunately took a " thoroughly unscientific course," and developed into a "specialist specialists." He had "very limited opportunities" and "neyer had the privilege of associating" with scientific men, although he displayed "malus animus" "towards those with whom he claims to be in fraternity." $\mathrm{He}$ is "totally destitute of any knowledge of chemical philosophy, and utterly untrustworthy as to any inquiry" not technical. His "assertions" are "well known in the scientific world to be inconsistent with fact." He enters on inquiries "with an avowed foregone conclusion of his own." He has "lent bimself to the support of wicked frauds." He has "prepossessions upon which clever cheats play." His "scientific tests" are not "worthy of trust." $\mathrm{He}$ is a believer in "day dreams," and the supporter of a "seetbing mass of folly and imposture ;" whilst, to crown all, he actually thinks that the radiomeler is driven " by the direct impetus of light." In short, this Pseudo. Crookes is a compound of folly and knavery such as has rarely, if ever, previously been encountered.

London, October 29 WilliaM CROOKES (The Ortho-Crookes?)

\section{Mr. Wallace and Reichenbach's Odyle}

I AM amazed that Dr. Carpenter should think it necessary to make public, with such haste, Prof. Hoffmann's statement that Baron Reichenbach's facts and theories are not accepted by the body of scientific men in Germany. Of course they are not. But how this affects their intrinsic accuracy I fail to see. Less than twenty years ago the scientific men of all Europe utterly disbelieved in the co-existence of man with extinct animals; yet the facts adduced by Freere, Boué, McEnery, Godwin Austen, Vivian, and Boucher de Perthes, are now admitted to have been trustworthy and deserving of the most careful examination. The whole history of scientific discovery from Galvani and Harvey to Jenner and Franklin, teaches us, that every great advance in science has been rejected by the scientific men of the period, with an: amount of scepticism and bitierness directly proportioned to the novelty and importance of the new ideas suggested and the extent to which they run counter to received and cherished theories. Rejection is one thing, disproof is another; and I have in vain searched for anything like disproof, or even rational explanation, of Reichenbach's facts : his theory, or "Odyledoctrine," I have never "attempted to rehabilitate," as Dr. Carpenter, with his usual misconception, says I have done. In my review of Dr. Carpenter's lectures (Quarterly Fournal o: Science, July, I877, p. 396), I adduce five tests employed by Reichenbach, and also the independent and simultaneous con. firmation of Dr. Charpignon in France; and the only reply I get is : "All men of science disbelieve them." With the facts of history above alluded to in my mind, and believing that human nature is very much the same in the nineteenth century as it was in the eighteenth, I can only say, "so much the worse for the men of science."

Dr. Carpenter's reference to the believers in a flat earth, as a parallel case, is unfortunate, because the two cases are really of a totally different nature. Those who maintain the earth to be flat do not deny the main facts which we rely or as proving it to be round, but they attempt to give other explanations of them. The dispute is on a question of reason and inference; and every intelligent and fairiy educated man is able to decide it for himself. But in Reichenbach's case it is the facts that are rejected without disproof or adequate explanation. The two cases are therefore quite distinct, and Dr. Carpenter's attempted parallel, as well as his setting up of scientific disbelief as a conclusive reply to evidence, is in conformity with his whole treatment of this subject.

I trust that such of the readers of NATURE as may feel any interest in the questions at issue between Dr. Carpenter and myself will read my article above referred to, and not allow themselves to be influenced by Dr. C,'s repeated appeals to authority and to prejudice. Alfred R. WAllace

I HAVE to requeit your insertion of a post-card I have this morning received, for two reasons; first, because, as it is anonymous, and as the writer of it is obviously a reader of NATURE, no other way is open to me for replying to it except that which your columns may afford; and secondly, because it is a very curious example of the misconceptions into which men are apt to fall who allow themselves to become "possessed" by "dominant ideas."

"If Mr. A. R. Wallace has to choose between being either 'a fool or a knave,' there is at all events no choice left for the man who deliberately and maliciously makes incorrect assertions and suppresses the truth to further his own views. I dare say you know what most people would call such a man. Yours,

$$
\text { "One who was at Plymouth" }
$$

Now, in the first case, it must be perfectly obvious to any one who is capable of reasoning logically, that nothing which I said of Mr. Wallace in your last number can be twisted into the implication that he is either " a fool or a knave" John Hampden is continually saying this of Mr. Wallace and of everybody who upholds the rotundity of the earth. And I mildly suggested whether, in putting himself in opposition to the whole aguregate of scientific opinion on the value of Reichenbach's Odylism-not because he had himself repeated them, but because he believes in Reichen. bach-Mr. Wallace is not assuming an attitude in some degree similar, that is, setting himself up as the one wise and honest man who duly appreciates Reichenbach, and therefore implying that everybody else is either stupidly or wilfully blind to the evidence he presented. If anyone thinks it worth whtle to read Mr. Wallace's review of my lectures on "Mesmerism, Spiritualism," \&c., in the last number of the Quarterly Fournal of Science, he will be able to judge whether I have or have not wronged Mr. Wallace in this matter.

The writer's appreciation of my own character, which has frea 